\title{
Karakteristik Remaja Pengguna Narkoba Suntik dan Perilaku Berisiko HIV/AIDS di Kecamatan Ciledug Kota Tangerang
}

\author{
Fauzi Syarif* Zarfiel Tafal ${ }^{* *}$
}

\begin{abstract}
Abstrak
Prevalensi penderita HIVIAIDS di Kota Tangerang yang merupakan daerah industri dari tahun ke tahun meningkat tajam. Kecenderungan peningkatan kemungkinan disebabkan oleh letak strategis Kota Tangerang yang berbatasan langsung dengan Jakarta serta dengan geografi dan demografi yang hampir sama dengan Jakarta. Bersamaan dengan itu kasus peredaran dan pemakaian narkotika di wilayah Tangerang dari tahun ke tahun meningkat tajam. Penelitian bertujuan untuk mengetahui hubungan antara karakteristik remaja pengguna narkoba suntik (penasun) dengan perilaku berisiko tertular HIVIAIDS di Kecamatan Ciledug Kota Tangerang Tahun 2007. Data yang dikumpulkan secara cross sectional dilakukan pada 206 sampel responden remaja berusia 15-24 tahun yang menggunakan narkoba suntik melalui wawancara langsung dengan berpedoman pada kuesioner. Karakterisitk remaja tersebut meliputi karakteristik: pribadi (pengetahuan tentang HIVIAIDS, jenis kelamin, umur, tingkat pendidikan, status ekonomi, posisi urutan dalam keluarga, status orang tua, dengan siapa tinggal), lingkungan sosial (keterpaparan pergaulan dengan pengguna narkoba, pola asuh orang tua, lingkungan tempat tinggal) dan karakteristik budaya (masyarakat fanatisme agama, daerah pendatang/campur, kegiatan di luar rumah). Penelitian menunjukkan gambaran perilaku remaja penasun yang berisiko tertular HIVIAIDS mencapai angka 55,3\%. Terdapat 8 (delapan) variabel yang berhubungan erat $(p<0,05)$ dengan perilaku penasun berisiko yaitu tingkat pengetahuan, umur, tingkat pendidikan, status ekonomi, status orang tua, pola asuh orang tua, lingkungan tempat tinggal dan kegiatan di luar rumah. Variabel yang paling dominan adalah tingkat pengetahuan dimana remaja penasun yang mempunyai tingkat pengetahuan kurang, mempunyai risiko tertular HIVIAIDS 6,9 kali dibandingkan yang mempunyai tingkat pengetahuan baik.
\end{abstract}

Kata kunci : Pengguna narkoba suntik, remaja, HIVIAIDS.

\begin{abstract}
Prevalence of HIV-AIDS in Tangerang City-an industrial area, continues to increase. The increase may be caused by location of Tangerang which is directly bordered to Jakarta and having similar geographical and demographical characteristics to Jakarta. At the same time, there is a significant increase of drugs distribution and abuse. This study aims at investigating the relationship between injection-drug-user (IDU) teenager's characteristics and HIV-AIDS high risk behavior in Ciledug Sub-district, Tangerang City in 2007. Data were collected through a cross-sectional survey conducted among 206 samples of IDU teenagers age 15-24 years old using questionnare administered in face-to-face interview. The study results show that HIV-AIDS risk behavior prevalence reached $55,3 \%$ among respondents and there were 8 variables with significant relationship $(p<0,05)$. Those 8 variables were knowledge, age, education level, economic status, parent status, parental care pattern, living environment, and outside home activity. The most dominant variable was knowledge where teenagers with low level of knowledge has 6,9 times higher risk of having HIV-AIDS risk behavior compared to those with higher level of knowledge.
\end{abstract}

Key words : IDU, teenagers, HIV-AIDS.

*Puskesmas Karang Tengah Kota Tangerang, Jl. Ciremai Raya Komplek Departemen Keuangan Kec. Karang Tengah Kota Tangerang Banten (e-mail: fauzisy@yahoo.com)

**Departemen Pendidikan Kesehatan dan IImu Perilaku Fakultas Kesehatan Masyarakat Universitas Indonesia, Gd. D Lt. 1 FKM UI, Kampus Baru UI Depok 16424 (e-mail: zarfiel_tafal2000@yahoo.com) 
HIV/AIDS (Human Immunodeficiency Virus/ Acquire Immuno Deficiency Syndrome) telah menjadi momok bagi masyarakat. Pada kurun waktu Januari Juli 2000, penyakit HIV memperlihatkan kecenderungan yang semakin meningkat dan menjadi ancaman bagi masyarakat. ${ }^{1}$ Jumlah kasus baru memperlihatkan kecenderungan yang semakin meningkat. Pada tahun 1999 kasus HIV (178) dan AIDS (47), pada tahun 2000 meningkat jadi HIV (192) dan AIDS (106). ${ }^{2}$ Di berbagai negara sekitar $50 \%$ Pengguna Narkoba Suntik (Penasun) hidup dengan HIV/AIDS. Bahkan di beberapa wilayah di dunia, sekitar $90 \%$ pemakai narkotik dengan jarum suntik hidup dengan HIV/AIDS. Lebih dari 95\% Penasun dengan HIV/AIDS terdapat di negara berkembang. Di seluruh dunia, AIDS telah menjadi penyebab kematian terbesar keempat pada orang dewasa. Kemungkinan lebih dari sepuluh juta paling sedikit satu juta Pengguna Narkoba Suntik (Injecting Drug User/IDU) di seluruh dunia menderita HIV atau AIDS. Penggunaan narkoba suntik telah dilaporkan oleh 129 negara, 103 diantaranya juga melaporkan infeksi HIV pada IDU. ${ }^{2}$ Saat ini HIV/AIDS telah menginfeksi seki$\operatorname{tar} 60$ juta orang di seluruh dunia dan lebih dari 21 juta diantaranya telah meninggal dunia. Setiap hari, orang yang terinfeksi bertambah sekitar 14.000 dan separuh diantaranya kelompok berusia muda antara 15-24 tahun. Di Afrika, setiap hari diperkirakan terjadi 5.500 kematian akibat AIDS. ${ }^{2}$

Kasus HIV pertama dilaporkan di Indonesia pada tahun 1987, ketika seorang laki-laki warga negara asing yang homoseksual meninggal dunia di Pulau Bali karena pneumonia dan sarkoma kaposi. ${ }^{3}$ Menurut Koordinator Program Akses Diagnosis Kelompok Studi Khusus (Pokdisus) AIDS FKUI/RSCM, Dr. Samsuridjal Djauzi SpPD, kasus baru yang datang ke Pokdisus AIDS sekitar $70 \%$ terkena HIV positif adalah pengguna narkotik suntik. Mereka kebanyakan termasuk golongan usia produktif (15-24 tahun). Saat ini status Indonesia telah meningkat dari status negara berprevalensi rendah (low prevalensi) menjadi berstatus epidemi terkonsentrasi (concentrated epidemic). Itu berarti bahwa di beberapa wilayah tertentu, lebih dari $5 \%$ populasi berisiko telah terjangkit HIV/AIDS.

Seluruh propinsi di Indonesia telah tersentuh oleh infeksi HIV/AIDS dan 6 propinsi dinyatakan harus mendapat prioritas dan perhatian khusus, akibat jumlah kasus HIV/AIDS yang tinggi. Wilayah tersebut adalah Papua, DKI Jakarta, Riau, Jawa Barat, Bali dan Jawa Timur. Jakarta menduduki tempat teratas sebagai propinsi dengan jumlah pengidap HIV/AIDS terbanyak. Penelitian menunjukkan bahwa $85 \%$ pengidap HIV/AIDS adalah kelompok usia produktif (20-49 tahun) oleh kaum pria memperlihatkan tren bepergian, meminum alkohol dan mengkonsumsi narkoba yang tinggi. $^{2}$

Kota Tangerang yang berbatasan langsung dengan Jakarta (termasuk Bandara Sukarno Hatta seluas 19,69 $\mathrm{km}^{2}$ ) mempunyai luas wilayah $183,78 \mathrm{~km}^{2}$. Kota Tangerang berjarak sekitar $80 \mathrm{~km}$ dari ibu kota Propinsi Banten dan $27 \mathrm{~km}$ dari DKI Jakarta. Jumlah penduduk pada tahun 2006 adalah 1.547.137 jiwa dengan laju pertumbuhan penduduk yang tinggi (1,94\% per tahun). Kota Tangerang yang sedang berkembang pesat berpotensi rentan terhadap transmisi penyakit HIV/AIDS, mengingat potensi dan daya tarik Kota Tangerang sebagai daerah penyangga Ibu Kota Negara Republik Indonesia dan sebagai daerah industri yang meningkat tajam merisaukan banyak orang tua. ${ }^{4}$ Hal tersebut terlihat pada kasus narkotika yang melibatkan pelajar terus bertambah dengan rata-rata hampir $100 \%$ setiap tahun. Berdasarkan data Polres Metro Tangerang, dalam kurun waktu enam bulan terakhir tercatat 1.148 kasus narkotika, yang melibatkan 1.519 tersangka dan memperlihatkan kecenderungan yang terus meningkat. Pada tahun 2000, jumlah kasus dan tersangka ( 76 dan 104), pada tahun 2005 (239 dan 345) terlihat meningkat sangat pesat. Wilayah dengan kasus narkotika tertinggi antara lain meliputi Kecamatan Tangerang, Jatiuwung, Cipondoh dan Ciledug.

Dampak sosial ekonomi yang terjadi akibat infeksi HIV/AIDS ternyata sangat memprihatinkan. Mulai dari biaya pengobatan mahal yang harus ditanggung keluarga, sampai penurunan produktifitas pada segala bidang secara nasional. Pengidap HIV/AIDS yang berasal dari keluarga miskin menjadi semakin miskin. Anak yatim piatu keluarga penderita AIDS harus merasakan penderitaan sosial yang berkepanjangan dengan menghilangnya dukungan dari keluarga dan masyarakat. ${ }^{5}$

Penularan HIV/AIDS paling tinggi terjadi melalui hubungan seksual dan IDU (Penasun). Dengan demikian, perilaku berperan penting dalam penularan HIV/AIDS. ${ }^{6}$ Oleh sebab itu, selain penanggulangan infeksi melalui tindakan medik, perlu ditanamkan perila$\mathrm{ku}$ aman melalui kampanye atau penyuluhan. Perubahan perilaku memerlukan bantuan perubahan emosional dan pengetahuan melalui proses yang mendorong nurani dan logika serta membutuhkan pendeka$\tan$ individual. ${ }^{7}$

\section{Metode}

Rancangan penelitian yang dipakai adalah non eksperimental. Data dikumpulkan secara cross sectional, yang mengukur variabel independen dan variabel dependen dalam waktu yang bersamaan. Pendekatan kuantitatif yang dilakukan dengan kuesioner terstruktur. Sasaran penelitian adalah remaja yang pernah/pengguna narkoba suntik yang tergabung dalam komunitas remaja peduli 
HIV/AIDS di bawah binaan Yayasan Pelita Ilmu yang bekerja sama dengan Dinas Kesehatan Kota Tangerang yang berada di Wilayah Kecamatan Ciledug Kota Tangerang. Populasi dalam penelitian ini adalah para remaja di Wilayah Kecamatan Ciledug Kota Tangerang yang pernah/menggunakan narkoba suntik. Jumlah sampel minimal dihitung dengan rumus disain studi cross sectional sampel satu kelompok. Dengan nilai $\alpha=0,05$, $\mathrm{p}=10 \%$ dan nilai $\mathrm{d}=0,064$; didapatkan jumlah sampel minimal 197. Pada penelitian ini semua subjek yang memenuhi kriteria disertakan dalam penelitian. Adapun yang termasuk kriteria populasi sebagai subjek penelitian adalah terbatas pada seluruh komunitas remaja peduli HIV/AIDS yang menggunakan narkoba suntik berusia $15-24$ tahun, yang berada di bawah pembinaan Yayasan Pelita Ilmu bekerja sama dengan Dinas Kesehatan Kota Tangerang yang berada di Kecamatan Ciledug Kota Tangerang. Remaja pengguna narkoba suntik di Kecamatan Ciledug Kota Tangerang berdasarkan laporan Yayasan Pelita Ilmu berjumlah 215 orang.

Pengolahan data dilakukan melalui empat tahap, (editing, coding, entry, cleaning data). ${ }^{8}$ Data diolah serta dianalisis dengan menggunakan program paket statistik, untuk melihat hubungan antara variabel-variabel independen dengan variabel dependen. Analisis univariat untuk melihat distribusi frekuensi masingmasing variabel bebas. Analisis bivariat untuk melihat hubungan antara variabel independen dan variabel dependen dengan uji statistik chi square dan derajat kemaknaan $\alpha=0,05$. Apabila hasil pengujian menghasilkan nilai $\mathrm{p}<0,05$ maka hubungannya secara statistik bermakna dan bila nilai $\mathrm{p}>0,05$ maka secara statistik tidak bermakna.

Hasil analisis bivariat dengan regresi logistik dipakai untuk menentukan variabel yang layak secara statistik diikutsertakan dalam model analisis selanjutnya (multivariat). Kandidat yang diikutsertakan dalam analisis multivariat mempunyai nilai $\mathrm{p} \leq 0,25.8$ Analisis multivariat dengan tujuan untuk melihat keeratan hubungan antara variabel independen secara bersama-sama dengan variabel dependen dan untuk menyertakan variabel yang paling dominan yang berhubungan perilaku berisiko tertular HIV/AIDS. Uji interaksi dilakukan pada model terbaik dan terakhir untuk melihat adanya interaksi dari variabel independen yang ada dalam model. Interaksi adalah suatu keadaan dimana hubungan satu variabel bebas dengan variabel terikat akan berbeda pola dan hubungannya pada tiap perubahan nilai variabel bebas yang lain. Dari nilai $\mathrm{p}$-value, dapat dilihat bila nilai $\mathrm{p}<0,05$ maka terjadi interaksi antar variabel. Variabel tersebut diikutkan dalam model, hingga diperoleh model matematik regresi logistik.

\section{Hasil}

\section{Uji Univariat}

Hasil uji univariat dapat diperoleh gambaran perilaku penasun. Responden dengan perilaku berisiko sebesar 55,3\% (Gambar 1). Responden yang berisiko merupakan responden pengguna narkoba suntik (injecting drug user/IDU) yang pernah berbagi jarum (menggunakan jarum bekas). Distribusi responden penasun menurut pengetahuan HIV/AIDS, responden dengan pengetahuan kurang $95(46,1 \%)$, pria $145(70,4 \%)$. Distribusi menurut umur $<23$ tahun $124(60,2 \%)$, tingkat pendidikan tinggi $176(85,4 \%)$, status ekonomi mapan $39(18,9 \%)$, ekonomi menengah $89(43,2 \%)$, ekonomi kurang $78(37,9 \%)$, anak tunggal $22(10,7 \%)$, anak sulung $64(31,0 \%)$, anak tengah $70(34,0 \%)$, anak bungsu $50(24,3 \%)$, orang tua kandung $164(79,6 \%)$, tinggal dengan orang tua $128(62,1 \%)$, tidak terpapar dengan pengguna narkoba $177(85,9 \%)$, pola asuh

Tabel 1. Frekuensi Distribusi Responden Berdasarkan Katagori Variabel yang Diamati

\begin{tabular}{lll}
\hline Variabel & Katagori & $\%$ \\
\hline Perilaku & Berisiko & 55,3 \\
Pengetahuan & Kurang & 46,1 \\
Jenis kelamin & Pria & 70,4 \\
Umur & $<23$ tahun & 60,2 \\
Pendidikan & Tinggi (>SMU) & 85,4 \\
Status Ekonomi & Mapan & 18,9 \\
& Menengah & 43,2 \\
Urutan dalam Keluarga & Sulung & 31,0 \\
& Tengah & 34,0 \\
Status Orang Tua & Bungsu & 24,3 \\
Tinggal Bersama & Tiri & 5,8 \\
Pajanan Pengguna Narkoba & Cerai & 14,8 \\
Pola Asuh Orang Tua & Bukan Orang Tua & 62,1 \\
Lingkungan Tempat Tinggal & Tak Terpajan & 14,1 \\
Fanatisme Agama Masyarakat & Otoriter & 28,6 \\
Daerah Pendatang/Campuran & Tidak Elit & 75,2 \\
Kegiatan Luar Rumah & Tidak & 52,9 \\
& Pendatang & 89,8 \\
\hline & Mengurung Diri & 18,9 \\
\hline
\end{tabular}

Tabel 2. Analisis Bivariat

\begin{tabular}{lll}
\hline Variabel & Katagori & Nilai p \\
\hline Pengetahuan & Kurang & 0.000 \\
Jenis Kelamin & Pria & 0.191 \\
Umur & $<23$ th & 0.009 \\
Pendidikan & Tinggi & 0.000 \\
Status Ekonomi & Mapan & 0.001 \\
Urutan dalam Keluarga & Tunggal Bungsu & 1,000 \\
Status Orang Tua & Tiri/cerai & 0.046 \\
Tinggal Bersama & Bukan Orang Tua & 0.923 \\
Pajanan Pengguna Narkoba & Terpajan & 0,856 \\
Pola Asuh Orang Tua & Otoriter & 0,000 \\
Lingkungan Tempat Tinggal & Tidak Elit & 0,000 \\
Fanatisme Agama Masyarakat & Ya & 0,075 \\
Kegiatan Luar Rumah & Bergaul & 0.000 \\
\hline
\end{tabular}


Tabel 3. Analisis Multivariat

\begin{tabular}{lclcl}
\hline Variabel & $\boldsymbol{\beta}$ & OR & 95\% CI OR & Nilai-p \\
\hline Pengetahuan & 1,427 & 4,18 & $2,10-8,24$ & 0.000 \\
Status Ekonomi & 1,076 & 0,341 & $1,5-0,79$ & 0,012 \\
Pola Asuh Orang Tua & 1,102 & 3,011 & $1,42-6,39$ & 0,044 \\
Kegiatan luar Rumah & 1,042 & 2,835 & $1,15-6,99$ & 0,24 \\
Constan & $-2,805$ & & & \\
\hline
\end{tabular}

Gambar 1. Perilaku Pengguna Narkoba Suntik

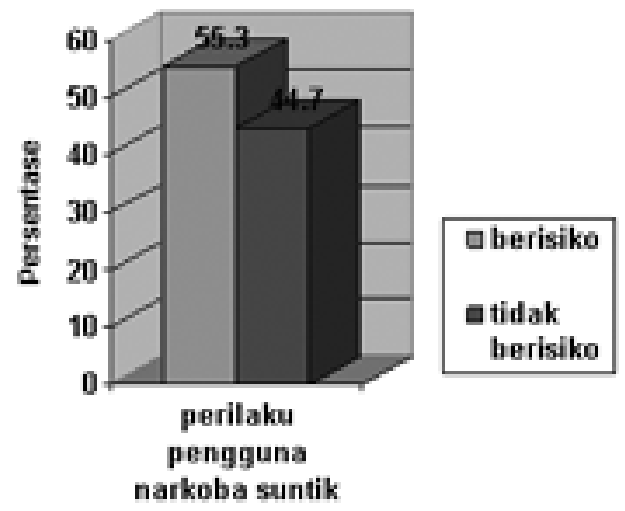

demokratis $147(71,4)$, tinggal dilingkungan tidak elit $155(75,2 \%)$, masyarakat fanatis agama $97(47,1 \%)$ tidak fanatis agama 109 (52,9\%), tinggal di lingkungan yang mempunyai masyarakat pendatang/campur 185 $(89,8 \%)$, mempunyai kegiatan di luar rumah 167 $(81,1 \%)$ (Lihat Tabel 1).

\section{Analisis Bivariat}

Analisis bivariat dengan uji Chi square memperlihatkan hubungan antara variabel bebas dengan variabel terikat dengan membandingkan nilai $\mathrm{p}$ value dan nilai $\alpha<$ 0,25 . Variabel bebas yakni variabel pengetahuan, jenis kelamin, umur, pendidikan, status ekonomi, status orang tua, pola asuh, posisi urutan dalam keluarga, masyarakat fanatisme agama dan memiliki nilai p-value yang lebih besar dari nilai $\alpha$ (Lihat Tabel 2).

\section{Uji Multivariat}

Uji multivariat dilakukan dengan metode Backward Wald yang tidak menyatukan semua variabel yang mempunyai nilai $\mathrm{p}>0,05$ dalam model. Pada akhirnya diperoleh model yang mengikutkan variabel bebas dengan nilai $\mathrm{p}<0,05$ (ada empat), yaitu tingkat pengetahuan, status ekonomi, pola asuh orang tua dan kegiatan di luar rumah yang secara bersama-sama berhubungan dengan perilaku pengguna narkoba suntik berisiko tertular HIV/AIDS. Untuk variabel kegiatan di luar rumah $(p>0,05)$ setelah dikeluarkan dalam model nilai $\mathrm{OR}>10 \%$, maka variabel tersebut tetap dipertahankan untuk masuk kedalam model. Selanjutnya dilakukan uji interaksi antara keempat variabel bebas tersebut. Apabila nilai $\mathrm{p}<0,05$ berarti terjadi interaksi antar variabel bebas untuk terjadinya variabel terikat, sebaliknya bila nila $p>0,05$ berarti tidak terjadi interaksi antara variabel bebas untuk terjadinya variabel terikat (Lihat Tabel 3).

\section{Uji Interaksi}

Hasilnya tidak ada interaksi ketiga variabel tersebut, yaitu antara tingkat pengetahuan, status ekonomi, pola asuh dan kegiatan di luar rumah, (dimana p-value semuanya $>0,05)$. Dengan demikian hasil penelitian menunjukkan empat variabel bebas yang dominan dan secara bersama-sama berhubungan dengan variabel terikat atau perilaku pengguna narkoba suntik berisiko tertular HIV/AIDS, yaitu variabel tingkat pengetahuan, status ekonomi, pola asuh orang tua dan kegiatan di luar rumah $(\mathrm{p}<0,05)$. Dalam bentuk model matematika, maka persamaan model regresi logistik yang menjelaskan perilaku remaja pengguna narkoba suntik berisiko tertular HIV/AIDS di Kecamatan Ciledug Kota Tangerang adalah:

$$
\mathrm{Y}(\text { Perilaku Penasun })=\frac{1}{\begin{array}{l}
1+\exp -(-2.805+1.427 \text { Tk.Peng }-1.076 \mathrm{St} . \mathrm{Ek}+1.102 \\
\text { pola asuh }+1.042 \mathrm{keg} \text { di luar rmh }
\end{array}}
$$

Dalam bentuk transformasi logit sebagai berikut: Logit (perilaku pengguna narkoba jarum suntik) $=-2.805$ $+1,427$ (tingkat pengetahuan) - 1,076 (status ekonomi) $+1,102$ (pola asuh) +1.042 (keg. di luar rumah)

Persamaan ini mempunyai arti bahwa apabila tingkat pengetahuan naik 1 (satu) satuan maka perilaku pengguna narkoba jarum suntik akan naik 1,427 satuan, apabila tidak ada perubahan pada sosial ekonomi dan pola asuh dan kegiatan di luar rumah. Begitu juga jika pola asuh naik 1 (satu) satuan maka perilaku pengguna narkoba jarum suntik akan naik 1,102 satuan, apabila tidak ada perubahan pada tingkat pengetahuan dan status ekonomi dan kegiatan diluar rumah. Nilai -2,805 merupakan nilai konstan yang merupakan titik potong garis persa- 
maan pada sumbu Y.

\section{Pembahasan}

Keterbatasan penelitian terjadi pada saat pelaksanaan penelitian yang dipengaruhi oleh kesalahan non sampling (non sampling error). Hal ini terjadi pada saat pelaksanaan di lapangan baik dari petugas wawancara dalam mengajukan pertanyaan atau kesalahpahaman responden atau salah tafsir akan maksud dari aspek yang ditanyakan pewawancara. Masalah ini bisa terjadi juga karena penggantian sampel atau karena responden dengan sengaja memberikan jawaban yang salah. Kesalahan non sampling sangat sulit dihindarkan, sehingga dalam pelaksanaan harus dengan perencanaan yang matang terutama bagi petugas pewawancara sendiri. ${ }^{9}$ Bias informasi dapat terjadi karena tingkat akurasi responden dalam mengingat riwayat faktor risiko berbeda pada setiap responden atau disebut juga bias recall. Kurang mendetailnya pertanyaan pada kuesioner dapat mengakibatkan bias informasi dalam penelitian ini. Pengumpulan data dengan menggunakan kuesioner bersifat sangat subjektif, sehingga kebenaran dan akurasi data sangat bergantung kepada kejujuran responden pada saat pengisian kuesioner. Lebih-lebih pada subjek penelitian (responden) adalah pengguna narkoba yang sulit untuk diharapkan kejujurannya. Untuk mengatasi keterbatasan kuesioner, beberapa variabel lain dilakukan pertanyaan pendukung sebagai validasi atas jawaban responden dan dilakukan uji validitas dan reliabilitas dengan melakukan wawancara kepada 30 responden dan dilakukan revisi kuesioner setelah ditemukan adanya kekurangan pada saat uji coba. Selain itu, peneliti dibantu oleh lima orang tenaga penjangkau (outreach) dari Yayasan Pelita Ilmu (YPI), sehingga responden tidak merasa asing kepada pewawancara dalam memberikan informasi.

Hasil analisis data menunjukkan bahwa variabelvariabel yang berhubungan dengan perilaku berisiko tertular HIV/AIDS adalah tingkat pengetahuan, status ekonomi, pola asuh orang tua dan kegiatan di luar rumah, $(\mathrm{p}<0,05)$. Variabel yang paling dominan ialah tingkat pengetahuan responden yang kurang. Hal ini kemungkinan karena kurangnya informasi atau penyuluhan baik dari pihak petugas kesehatan maupun pihak-pihak yang berwenang dalam penanggulangan narkoba. Variabel status ekonomi, didapatkan bahwa yang lebih berisiko tertular ialah responden dengan status ekonomi menengah ke bawah. Hal ini dapat disebabkan oleh lapangan pekerjaan bagi para penasun yang kurang sehingga banyak diantara penasun yang mengambil risiko berbagi jarum dalam menggunakan narkoba. Variabel pola asuh orang tua, penelitian menunjukkan bahwa pola asuh demokratis ternyata lebih berisiko dibanding pola asuh otoriter. Hal ini kemungkinan karena kebanyakan para orang tua dengan pola asuh demokratis mem- berikan kebebasan tanpa batas kepada anak-anaknya, sehingga anaknya tidak terkontrol dalam berperilaku dalam pergaulannya.

Untuk variabel kegiatan di luar rumah, penelitian menunjukkan ternyata anak yang suka bergaul luar rumah lebih berisiko dibanding anak yang cenderung mengurung diri. Hal ini kemungkinan karena anak yang bergaul dengan kontrol orang tua yang lemah, ekonomi kurang dan pengetahuan yang kurang tidak mempunyai pertahanan diri yang kuat dalam menerima arus pergaulan yang negatif sehingga membawa pengaruh untuk mengikuti pergaulan yang bersifat negatif. Kemungkinan lebih ialah di luar rumah peluang terpapar narkoba dan jarum suntik lebih besar.

\section{Kesimpulan}

Responden yang pernah menggunakan narkoba suntik pernah berbagi jarum atau menggunakan jarum bekas pakai. Karakteristik pribadi yang berhubungan bermakna secara statistik adalah: pengetahuan, umur, tingkat pendidikan dan status ekonomi. Karakteristik lingkungan sosial yang berhubungan bermakna adalah pola asuh orang tua dan lingkungan tempat tinggal. Karakteristik budaya yang berhubungan bermakna adalah kegiatan di luar rumah. Variabel-variabel yang berhubungan dengan perilaku pengguna narkoba suntik berisiko adalah tingkat pengetahuan kurang, status ekonomi kurang, pola asuh orang tua yang demokrasi dan kegiatan di luar rumah.

\section{Saran}

Dinas Kesehatan Kota Tangerang disarankan meningkatkan promosi kesehatan dan penyuluhan tentang narkoba kepada para remaja khususnya. Program surveilans perilaku kesehatan atau Risk Behavioral Surveillance Survey (BSS) pada remaja pengguna narkoba suntik di lingkungan Lembaga Permasyarakatan (LP) Pemuda dan komunitas remaja lainnya yang bergabung dalam LSM peduli AIDS perlu dilakukan. Pemerintah Daerah Kota Tangerang disarankan berkoordinasi dengan KPAD (Komisi Penanggulangan AIDS Daerah) dan lembaga legislatif (DPRD). Menyediakan lapangan kerja bagi para remaja perilaku berisiko yang lebih luas, disamping membuat undang-undang yang dapat memberikan efek jera kepada para pengguna narkoba. Lembaga Swadaya Masyarakat disarankan melakukan penyuluhan yang intensif tentang bahaya narkoba dan bekerjasama dengan pemerintah daerah dalam penanggulangan remaja korban penyalahgunaan obat-obatan khususnya narkoba. Para peneliti disarankan mengadakan penelitian lanjut dengan memperluas daerah/area penelitian, tidak terbatas pada satu kecamatan dan antara lain dengan metode kualitatif. Para orang tua disarankan lebih waspada dan mendampingi anak remajanya, terutama yang menerapkan pola asuh demokratis. 


\section{Daftar Pustaka}

1. Clatts MC, Giang Ie M, Goldsamt LA, Yi H. Novel heroin injection practices: implications for transmission of HIV and other bloodborne pathogens. Am J Prev Med. 2007; 32(6 Suppl): S226-33.

2. Departemen Kesehatan RI Ditjen PPM \&PL. Rencana strategi penanggulangan HIV/AIDS Indonesia. Jakarta: Departemen Kesehatan RI; 2002.

3. Iskandar, Meiwita D; Ariawan, Iwan; Dharmaputra Nick G. Analisis situasi HIV/AIDS dan dampaknya terhadap anak-anak, wanita, keluarga di Indonesia. Jakarta: Puslitkes UI; 1996.

4. Dinas Kesehatan Kota Tangerang. Laporan hasil kegiatan surveilans subdin P2M-PL dinas kesehatan kota Tangerang. Tangerang: Dinas Kesehatan Kota Tangerang; 2006.
5. Save the Children. HIV/AIDS, the risk to indonesia's children and young people. Jakarta; 2004.

6. Hennink M, Abbas Z, Choudhri Y, Diener T, Lloyd K, Archibald CP, Cule S. Risk behaviours for infection with HIV and hepatitis $\mathrm{C}$ virus among people who inject drugs in Regina, Saskatchewan. Can Commun Dis Rep. 2007; 33(5): 53-9.

7. Komisi Penanggulangan Aids Nasional. Peta pelayanan perawatan, dukungan dan pengobatan untuk ODHA di Indonesia. Jakarta: KPA dan Tim; 2006.

8. Sabri, Luknis dan Sutanto Priyo Hastono. Statistik kesehatan. Jakarta: Raja Grafindo Persada; 2006.

9. M, Singarimbun dan Effendi S. Metode penelitian survei. LP3ES. 1989; ix: 336 . 